\title{
Real Exchange Rates and Growth: Contractionary Depreciations or Appreciations?
}

\author{
Duygu YOLCU KARADAM ${ }^{1}$ ๑ , Erdal ÖZMEN² @
}

\begin{abstract}
This study investigates the impact of real exchange rates (RER) on growth of a large number of advanced (AE) and developing economies (DE) estimating conventional growth models augmented with global financial conditions variables. First of all, replicating Rodrik (2008) and following studies employing panel autoregressive distributed lag (PARDL) and PARDL mean group (PARDL-MG) models, we show that the expansionary depreciation findings for DE are often based on a misinterpretation of an error correction mechanism coefficient. Then, we investigate the relationship between RER and growth explicitly taking into account balance sheet or external debt vulnerabilities which often do not considered by conventional growth literature. Fully-Modified OLS estimation results show that, the external variables demonstrating global financial and monetary conditions are strongly significant in explaining growth in DE along with the conventional domestic variables including trade openness, human capital and savings. Furthermore, our results suggest that, RER depreciations are contractionary for DE with high external debt and expansionary for AE. However, higher trade openness decreases the contractionary impact of depreciations in both $A E$ and DE. These results are robust for different RER and real income measures.
\end{abstract}

Key words: Balance Sheets, Developing Economies, Growth, Real Exchange Rates, Panel Data

JEL Classification: F30, F41, F60, F65, 011.

\section{Introduction}

In the Mundell-Fleming framework, which maintains that as long as the Marshall-Lerner conditions hold, real exchange rate (RER) depreciations are expansionary as they make tradable sectors more competitive. The success of China and some other East Asian countries with high growth under undervalued RER has been taken as evidence for this postulation. According to Rodrik (2008), for instance, systematic RER undervaluations facilitate economic growth in developing economies (DE) by making tradable sectors more profitable which are affected from institutional problems and market inefficiencies to a more extent.

RER depreciations, according to Levy-Yeyati, Sturzenegger and Gluzmann (2013), are expansionary not through the "neo-mercantalist" trade competitiveness channel but, instead, through higher domestic savings. In the absence of external vulnerabilities, the higher savings impact of depreciations is consistent with Diaz-Alejandro (1965) suggesting that RER depreciations lead to income transfer from labour to capital and thus to higher savings through this regressive income distribution.

The "mercantilist" or "savings" channels, however, do not consider the impacts of RER depreciation on high foreign currency (FX) debt or the net financial positions of firms with high liability dollarization (LD). In this context, another strand of the literature, following the balance sheet (BS) channel (see, among others, Krugman 1999; Calvo, Izquerdo and Mejía 2004), often finds that RER depreciations are contractionary in DE due to mainly the presence of high LD. Under high LD and high FX debt, currency mismatches between assets 
and liabilities, lead to deterioration of the net worth of the economy in the face of real depreciations.

The BS literature provides a strong rationale for contractionary RER depreciations. However, there is only a very limited number of studies investigating the relationship between RER and growth explicitly taking into account BS or external debt vulnerabilities. Furthermore, the empirical growth literature often ignores integration and cointegration properties of variables (Eberhardt and Teal, 2011) and estimates unbalanced equations including I(1) and I(0) variables. Another important contribution of this paper is that, "undervaluation" variable coefficient in studies following Rodrik (2008), indeed, may be representing an error correction mechanism instead of supporting the expansionary devaluations postulation. Furthermore, growth of $D E$ is often determined by not only domestic fundamentals, but also global financial conditions. The conventional growth literature, however, often does not consider such variables. This paper attempts to fill these important gaps in the literature also by employing the recent panel data estimation procedures.

The plan for the rest of the paper is as follows. Section II presents a brief literature review. Section III presents empirical results. In Section III.1, we attempt to replicate the results by Rodrik (2008) and the following studies. The main finding of this section, based on simple panel autoregressive distributed lag (PARDL) and PARDL mean group (PARDL-MG) models, is that the results supporting expansionary devaluations in DE should be interpreted with an extreme caution, as they may be, indeed, representing an adjustment to deviations from cointegration between real exchange rates and per capita real output.

Economic growth of $D E$ is shown to be highly dependent on the global monetary and financial conditions (Kose, Otrok and Prasad 2012; Erdem and Özmen 2015). Therefore, section III.2, considers a conventional growth model augmented with variables representing external financial and monetary conditions. In the context of the BS literature, this section also investigates the impact of external debt and its interaction with RER on growth. Considering the potential endogeneity of the domestic explanatory variables for the long-run evolution of growth, we estimate the models by employing fully modified OLS (FM-OLS) procedure which considers endogeneity, serial correlationa and heterogeneity in the long-run relationships Finally, Section IV concludes and provides some policy implications.

\section{A Brief Review of The Literature}

Under the Mundell-Fleming framework and the Marshall-Lerner conditions, RER depreciations positively affects growth since they lead to a more competitive tradable sector. According to this "neo-mercantilist" mechanism (Levy-Yeyati, Sturzenegger and Gluzmann 2013), systematically under-valued domestic currency shifts domestic production from nontraded to traded goods which have a higher total factor productivity. According to Rodrik (2008), for instance, by increasing the profitability of the tradable sector, RER undervaluation facilitates economic growth in DE. The success of some East Asian countries with high growth under undervalued RER has been taken as evidence supporting this postulation. Recently, Guzman, Ocampo and Stiglitz (2018) suggest that stable and competitive real exchange rate policies can promote economic development if it is supported by macro stability and industrial policies.

The neo-mercantalist view, however, provides no systematic monetary policy rule or transmission mechanism to maintain a sustained undervalued RER under flexible exchange regimes and inflation targeting. Diaz-Alejandro (1965) suggests that RER depreciations cause income transfer from labour to capital and this regressive income distribution leads to higher domestic savings and lower growth. The higher savings impact of RER depreciations provides also a starting point for the recent expansionary devaluations arguments (Gluzmann, Levy-Yeyati and Sturzenegger 2012; Levy-Yeyati, Sturzenegger and Gluzmann 2013). Real devaluations relax the binding borrowing constraints of firms by means of saving channel. Eichengreen (2008), argues that both the competitiveness and savings (due to higher growth) are important determinants of expansionary RER depreciations.

The recent evidence on the impact of RER on growth is mixed. The results by Rodrik (2008), Di Nino, Eichengreen and Sbracia (2011), Gluzmann, Levy-Yeyati and Sturzenegger (2012) and Levy-Yeyati , Sturzenegger and Gluzmann. (2013) all provide empirical support for the expansionary RER depreciation postulation for DE. In all these studies, RER are "corrected" for the Balassa-Samuelson effect. Bussiere, Lopez and Tille (2015) finds that RER appreciations lead to productivity increases and have a greater impact on growth than those due to capital inflows RER appreciations, per se, are found to be contractionary. Montiel and Serven (2008), on the other hand, argues that there is only weak analytical or empirical support for the 
argument that systematic RER depreciations promote increased domestic saving and consequently higher domestic capital accumulation and growth. Ahmed, Kamin and Huntley (2002) finds that devaluations tend to be expansionary in $\mathrm{AE}$ and contractionary in $\mathrm{DE}$. According to Alper and Civcir (2012), whilst large and persistent devaluations are associated with financial crises, relatively small and transitory RER appreciations promotes growth of Turkish economy. Nouira and Sekkat (2012) reports that they do not find any strong support for the expansionary undervaluation claim for a panel of $52 \mathrm{DE}$. For a panel data set of 150 countries, Habib, Mileva and Stracca (2017) reports a robust and significant effect of real appreciation on real GDP per capita growth once they control simultaneity problem with instrumentation approach. Their results show that the effect is stronger for developing countries and countries with pegging currency. Focusing on euro area economies, Lane and Stracca (2018) points out that a real appreciation creates a trade-off between expenditure switching (expansionary) and terms of trade (contractionary) effects while the latter dominates in most of the countries. Their findings reveal that the effects of appreciations are different especially for 'core' and 'peripheral' countries at which appreciations lead to more growth but also more current account imbalances.

An important consequence of the expansionary RER depreciations is the "fear of appreciation" in DE (Levy-Yeyati, Sturzenegger and Gluzmann, 2013). This clearly contradicts with the "fear of floating" argument by Calvo and Reinhart (2002). The presence of pervasive liability dollarisation (LD) is the basic reason of "fear of floating" in DE. High level of LD and FX debt, indeed provides the basic starting point of contractionary RER depreciations argument in the context of the balance sheet (BS) literature (Krugman 1999; Calvo, Izquierdo and Mejía 2004; Frankel 2005). The contractionary RER depreciations due to high FX debt, which is closely related with $L D$, was indeed clearly identified much earlier by Diaz-Alejandro (1965)'.

According to the BS literature, real decisions of economic agents, basically firms, depend crucially on their financial positions. Financial positions of economic agents, may considerably vary due to the currency denomination of their balance sheets and, in turn, the elasticity of their net income to RER. RER depreciations affect BSs significantly due to currency and time mismatches in the presence of high LD and FX debt. Consequently, borrowing capacity of firms de- teriorates decreasing their investment and production. Total effect of RER is an empirical issue and critically depends on sector/country characteristics such as their import dependence of production, FX debt along with currency composition of BS.

Frankel (2011) suggests that weak BS due to LD leads to not only contractionary devaluation, but also currency crises. According to Cespedes, Chang and Velasco (2003), negative BS effect dominates competitiveness effect when the economy has high debt to net worth ratio, high FX debt and underdeveloped financial markets. Céspedes (2005) finds that output is significantly affected from the presence of large external debt and real devaluations. Ahmed, Kamin and Huntley (2002) finds that contractionary devaluations are often the case for DE. Galindo, Panizza and Schiantarelli (2003) suggest that traditional competitiveness impact of depreciations on investment reverses in the case of high LD. Kesriyeli, Özmen and Yiğit (2011) reports that RER depreciations are contractionary for non-financial sectors of Turkey. Bebczuk, Galindo and Panizza (2006) finds that when external dollarization or debt exceeds a certain level, contractionary effect of devaluation dominates the trade competitiveness effect.

\section{Data, Model and Empirical Results}

\subsection{Expansionary Depreciations or an Error Correction Mechanism?}

To investigate the relationship between real exchange rates and growth, we first consider the baseline model $^{2}$ of Rodrik (2008):

$$
\Delta y_{i t}=a_{0}+a_{1} U N D E R V A L_{i t}+u_{i t}
$$

where UNDERVAL are the residuals from the estimation of:

$$
\operatorname{rer}_{i t}=b_{0}+b_{1} y_{i t}+v_{i t}
$$

In Eq. (1), $y=\ln (R G D P), R G D P=$ per capita real GDP at constant 2010 USD, reer $=\ln (\mathrm{RER}), \mathrm{RER}=$ real effective US\$ exchange rate. We first use the real exchange rate index of the International Monetary Fund (IMF), RER ${ }^{\text {IMF. }}$. For robustness check we consider also the "price level of GDP" data by Penn World Tables (PWT) version 9.0 and define $\mathrm{RER}^{\mathrm{PWT}}{ }_{\text {it }}$ as $P P P_{i t} / \mathrm{XR}_{\text {it }}$ where $\mathrm{XR}$ is the nominal exchange rate and PPP is the purchasing power parity conversion factor. Consequently, an increase in $\mathrm{RER}^{\mathrm{PWT}}$ means real appreciation. Rodrik (2008), and Gluzmann, 
Levy-Yeyati and Sturzenegger (2012) define RER ${ }^{\mathrm{PWT}}{ }_{\text {it }}$ as $\mathrm{XR}_{\mathrm{it}} / \mathrm{PPP}_{\mathrm{it}}$ and thus an increase in $\mathrm{RER}^{\mathrm{PWT}}$ means real depreciation. Our unbalanced panel data contain 25 $A E$ and 66 DE for the annual period of 1980-2014. The choice of countries is determined by data availability. Tables $A 1$ and $A 2$ of the Appendix present the data sources and the full list of countries, respectively.

According to Rodrik (2008), UNDERVAL is the RER "corrected"for the Balassa-Samuelson postulation suggesting that higher productivity causes appreciation ${ }^{3}$. A similar procedure is employed also by some other studies supporting expansionary depreciations, including Di Nino, Eichengreen and Sbracia (2011), Levy-Yeyati, Sturzenegger and Gluzmann (2013) and Gluzmann, Levy-Yeyati and Sturzenegger (2012). Following Rodrik (2008), we estimate (1) and (2) by employing panel fixed effects procedure.

Consistent with the findings of Rodrik (2008), the estimation of (2) yielded the slope coefficient estimates as 0.38 for rer $^{\mathrm{PWT}}$ and 0.22 for rer ${ }^{\mathrm{MF} F}$ with highly significant t-statistics. Rodrik (2008) interprets such result as supporting the Balassa-Samuelson postulation. The results of the Levin, Lin and Chu (2002) panel unit root tests (the lag lengths chosen as 3 by Akaike Information criterion, AIC) yielded -6.26 for rer ${ }^{\mathrm{PWT}}$ and -6.48 for rer ${ }^{\mathrm{MMF}}$, strongly suggesting the stationarity of the equation residuals. Considering the finding that the variables are integrated of order one (I(1), see Table 3 , below), this result, suggests the presence of a long-run equilibrium relationship (cointegration) between real exchange rates and per capita real GDP4.

Table 1 shows estimation results of equation (1) for the whole sample. The results appear to support the Rodrik (2008) finding that real depreciations are expansionary for both measures of real exchange rates. Table 1 contains also the estimation of equation (1) using UNDERVAL $L_{\text {it- }}$ instead of ${ }^{5}$ NDERVAL $L_{\text {it }}$. The results remain essentially the same both for rer ${ }^{\mathrm{MMF}}$ and rer $^{\mathrm{PWT}}$.
Given that rer $_{\text {it }}$ and $\mathrm{y}_{\text {it }}$ are cointegrated, the UNDERVAL $L_{\text {it }}$ variable (residuals from the regression of rer $_{\text {it }}$ on $y_{i t}$ ) may, indeed, be representing deviations from long-run equilibrium. As already noted, UNDERVAL is a stationary combination of two I(1) variables, rer $_{\text {it }}$ and $\mathrm{y}_{\mathrm{it}}$. Consequently, the UNDERVAL $\mathrm{it}_{\mathrm{it}}$ coefficient $\left(\mathrm{c}_{1}\right)$ in:

$$
\Delta y_{i t}=c_{0}+c_{1} U N D E R V A L_{i t-1}+e_{i t}
$$

may, indeed, be representing the adjustment coefficient in an error correction mechanism (EC) set up, rather than a real exchange rate impact. Therefore, the negative UNDERVAL $L_{\text {it- } 1}$ coefficients in equations (1.3) and (1.4) may better be interpreted as suggesting real income adjusting to deviations from long-run equilibrium rather than supporting the expansionary real depreciation postulation.

We consider also the following reparametrized simple panel autoregressive distributed lag (PARDL) model:

$\Delta y_{i t}=d_{0}+d_{1} E C_{i t-1}+d_{2} \Delta y_{i t-1}+d_{3} \Delta r e r_{i t-1}+v_{i t}$

In (4) $\mathrm{EC}_{\mathrm{it}-\mathrm{1}}$ is indeed UNDERVAL $\mathrm{it}_{\mathrm{i}-1}$ and consequently the coefficient of this gives the adjustment coefficient. A negative and significant $d_{1}$ estimate simply suggest that real income adjusts to deviations from the longrun equilibrium. Equations (1.5) and (1.6) in Table 1 presents the results. The estimated EC coefficients are essentially the same with the coefficients UNDERVAL $L_{\text {it }}$ in Eqs. (1.1) and (1.2). Consequently, the interpretation of UNDERVAL ${ }_{\text {it }}$ coefficients as the impact of real exchange rate may be seriously misleading and thus should be taken with an extreme caution.

We now proceed with the estimation of the following PARDL mean group (PARDL-MG) model:

$$
\Delta y_{i t}=e_{0}+e_{1} E C_{i t-1}+e_{21} \Delta y_{i t-1}+\ldots+e_{2 p} \Delta y_{i t-p}+e_{30} \Delta r e r_{i t}+\ldots+e_{3 p} \Delta r e r_{i t-p}+v_{i t}
$$

The PARDL approach can be employed even if the variables are integrated of order zero or one and are not weakly-exogenous. (Pesaran, Shin and Smith 1999; Chudik and Pesaran 2015). The PARDL-MG procedure assumes the long run coefficients are the same but allow the short-run and EC coefficients to be different across countries. The EC and short-run PARDL-MG coefficients can be found by taking the simple averages of individual country coefficients. Table 2 reports the PARDL-MG results 6 . Accordingly, RER appreciations are contractionary for $A E$ (eq. 2.2) and expansionary for $D E$ (eq. 2.3). The significant $E C_{t-1}$ coefficients support the hypothesis that real income adjusts to deviations from the long-run equilibrium. 
Table 1: "Undervaluation”, Growth and Error Correction Mechanism

\begin{tabular}{|c|c|c|c|c|c|c|}
\hline & \multicolumn{6}{|c|}{ Real Exchange Rate Measure } \\
\hline & $\operatorname{rer}^{\mathrm{PWT}}$ & rermF & $\operatorname{rer}^{\mathrm{PWT}}$ & rer $^{\mathrm{IMF}}$ & $\operatorname{rer}^{\mathrm{PWT}}$ & rer IMF \\
\hline Equation & 1.1 & 1.2 & 1.3 & 1.4 & 1.5 & 1.6 \\
\hline intercept & $\begin{array}{l}0.018^{* *} \\
(0.001)\end{array}$ & $\begin{array}{l}0.018^{* *} \\
(0.001)\end{array}$ & $\begin{array}{l}0.018^{* *} \\
(0.001)\end{array}$ & $\begin{array}{l}-0.018^{* *} \\
(0.001)\end{array}$ & $\begin{array}{l}0.016^{* *} \\
(0.001)\end{array}$ & $\begin{array}{l}0.014^{* *} \\
(0.001)\end{array}$ \\
\hline UNDERVAL $_{\text {it }}$ & $\begin{array}{l}-0.013^{* *} \\
(0.005)\end{array}$ & $\begin{array}{l}-0.016^{* *} \\
(0.004)\end{array}$ & & & & \\
\hline UNDERVAL $_{\mathrm{it}-1}$ & & & $\begin{array}{l}-0.017^{* *} \\
(0.003)\end{array}$ & $\begin{array}{l}-0.019 * * \\
(0.004)\end{array}$ & $\begin{array}{l}-0.017^{* *} \\
(0.003)\end{array}$ & $\begin{array}{l}-0.016^{* *} \\
(0.003)\end{array}$ \\
\hline$\Delta \operatorname{rer}_{\mathrm{it}-1}$ & & & & & $\begin{array}{l}-0.007 \\
(0.006)\end{array}$ & $\begin{array}{l}-0.002 \\
(0.006)\end{array}$ \\
\hline$\Delta y_{i t-1}$ & & & & & $\begin{array}{l}0.256 \\
(0.018)^{* *}\end{array}$ & $\begin{array}{l}0.223 \\
(0.019)^{* *}\end{array}$ \\
\hline Diagnostics & $\begin{array}{l}N=91 \\
N T=2847 \\
R^{2}=0.25 \\
F=7.19\end{array}$ & $\begin{array}{l}N=91, \\
N T=2724 \\
R^{2}=0.25 \\
F=7.11\end{array}$ & $\begin{array}{l}N=91 \\
N T=2836 \\
R^{2}=0.26 \\
F=7.47\end{array}$ & $\begin{array}{l}N=91 \\
N T=2700 \\
R^{2}=0.26 \\
F=7.44\end{array}$ & $\begin{array}{l}N=91, \\
N T=2756 \\
R^{2}=0.32 \quad F=9.94\end{array}$ & $\begin{array}{l}\mathrm{N}=91 \\
\mathrm{NT}=2619 \\
\mathrm{R}^{2}=0.32 \mathrm{~F}=9.30\end{array}$ \\
\hline
\end{tabular}

Notes. Standard errors are given in parentheses. ${ }^{* *}$ denotes the significance at the $5 \%$ level, N and NT represents the the effective numbers of countries and observations, respectively.

Table 2: Real Exchange Rates and Growth: PARDLMG Results

\begin{tabular}{|c|c|c|c|}
\hline $\begin{array}{l}\text { Country } \\
\text { Grouping }\end{array}$ & ALL & $\mathrm{AE}$ & $\mathrm{DE}$ \\
\hline Equation & 2.1 & 2.2 & 2.3 \\
\hline \multicolumn{4}{|c|}{ Long-Run } \\
\hline $\operatorname{rer}_{\text {it }}^{\text {IMF }}$ & $\begin{array}{l}0.900 * * \\
(0.043)\end{array}$ & $\begin{array}{l}-1.612^{* *} \\
(0.191)\end{array}$ & $\begin{array}{l}0.947^{* *} \\
(0.053)\end{array}$ \\
\hline \multicolumn{4}{|c|}{ Short-Run } \\
\hline$E C_{t-1}$ & $\begin{array}{l}-0.027^{* *} \\
(0.007)\end{array}$ & $\begin{array}{l}-0.031^{* *} \\
(0.006)\end{array}$ & $\begin{array}{l}-0.033^{*} \\
(0.019)\end{array}$ \\
\hline$\Delta \operatorname{rer}_{\text {it }}^{\mathrm{IMF}}$ & $\begin{array}{l}-0.031 \\
(0.032)\end{array}$ & $\begin{array}{l}-0.022 \\
(0.039)\end{array}$ & $\begin{array}{l}-0.002 \\
(0.041)\end{array}$ \\
\hline$\Delta \operatorname{rer}^{\mathrm{IMF}}{ }_{\mathrm{it}-1}$ & $\begin{array}{l}-0.082^{* *} \\
(0.016)\end{array}$ & & \\
\hline$\Delta y_{i t-1}$ & $\begin{array}{l}0.232^{* *} \\
(0.027)\end{array}$ & $\begin{array}{l}0.297^{* *} \\
(0.038)\end{array}$ & \\
\hline intercept & $\begin{array}{l}0.169 * * \\
(0.037)\end{array}$ & $\begin{array}{l}0.620^{* *} \\
(0.108)\end{array}$ & $\begin{array}{l}0.196^{* *} \\
(0.088)\end{array}$ \\
\hline Sample & $\begin{array}{l}N=91 \\
N T=2610\end{array}$ & $\begin{array}{l}\mathrm{N}=25, \\
\mathrm{NT}=823\end{array}$ & $\begin{array}{l}\mathrm{N}=66, \\
\mathrm{NT}=1834\end{array}$ \\
\hline
\end{tabular}

Notes. Standard errors are given in parentheses. $* *$ denotes the significance at the $5 \%$ level, N and NT represents the the effective numbers of countries and observations, respectively.

The empirical growth literature often ignores integration and cointegration properties of the data and estimates unbalanced equations including $\mathrm{I}(1)$ and $\mathrm{I}(0)$ variables $^{7}$. The results of this paper, so far, highlight the importance of this and related issues. RER changes, per se, may also be reflecting omitted domestic macroeconomic fundamentals and global financial conditions beyond the variables already contained in equations 1.1-1.6. The following section proceeds with the estimation of a growth model.

\subsection{Real Exchange Rates and Growth: Evidence from a Growth Model}

To estimate the relationship between real exchange rates and growth, we now consider the following equation:

$$
y_{i t}=\gamma_{0}+\gamma_{1} \operatorname{rer}_{i t}+D_{i t}^{\prime} \gamma_{2}+E_{t}^{\prime} \gamma_{3}+u_{i t}
$$

where, rer ${ }_{i t}$ is rer ${ }_{i t^{\prime}} \mathrm{D}_{t}^{\prime}$ and $\mathrm{E}_{\mathrm{t}}^{\prime}$ are the transposes of the vectors of, respectively, domestic and external variables, $\gamma_{2}$ and $\gamma_{3}$ are the corresponding vector of coefficients and $u_{i t}$ is the error term ${ }^{8}$. $D^{\prime}$ contains the main variables postulated by the growth literature ${ }^{9}$. These include human capital, based on years of schooling and returns to education ( $\mathrm{HC}$, Feenstra, Inklaar and Timmer, 2015), trade openness (OPEN, expressed as the sum of exports and imports over GDP) and domestic savings (SAV, as a share of GDP).

Business cycles and economic growth of DE are supposed to be highly affected from global financial conditions (Kose, Otrok and Prasad 2012; Erdem and 
Özmen 2015; Almansour, et al. 2015). Many DE yields respond to "world interest rates" (Bahadir and Lastrapes, 2015). Borrowing costs of DE in international markets are often determined by global financial conditions (Gonzalez-Rozada and Levy-Yeyati 2008; Özatay, Özmen and Şahinbeyoğlu 2009; Özmen and Yaşar 2016).

The external variables in (6) contain fed rate and vix where fed rate is $\ln \left(1+R^{\mathrm{FED}} / 100\right)$ with $\mathrm{R}^{\mathrm{FED}}$ being the FED Funds target rate ${ }^{10}$ and vix is the log of volatility implicit in U.S. stock options (VIX). The FED target rate is postulated to proxy monetary policy conditions in the USA. VIX represents liquidity conditions and risk appetite globally (Gonzalez-Rozada and Levy-Yeyati 2008). According to Rey (2015), VIX goes in line with global financial conditions which lead to booms and busts in DE. The equations which include VIX are estimated for 1990-2014 period since VIX data can be found after 1990.

Considering the potential endogeneity of the domestic explanatory variables for the long-run evolution of growth, we estimate (6) by employing fully modified OLS (FM-OLS) procedure ${ }^{11}$ (Pedroni, 2000). The FM-OLS procedure considers endogeneity, autocorrelation and potential heterogeneity in the long-run relationships. As already noted, the conventional growth literature often ignores integration and cointegration properties of the data and estimates unbalanced equations including I(1) and $\mathrm{I}(0)$ variables. FM-OLS takes this issue into account in the sense that endogeneity of the variables does not affect the estimation results since FM-OLS estimates are superconsistent when variables are cointegrated.

Table 3 reports the results of Levin, Lin and Chu (2002) panel unit root tests (LLC) for the panel variables and augmented Dickey-Fuller tests for vix and fed rate. The results of the tests suggest that all the variables in (5) are I(1) ${ }^{12}$. Table 4 reports the FM-OLS results for country groupings. The results of the LLC tests suggest that the equation residuals are stationary. Consequently, the equations in Table 4 may be interpreted as representing a long-run equilibrium relationships (cointegration) ${ }^{13}$.

According to equations 4.1-4.4, human capital $(\mathrm{HC})$, domestic savings (SAV) and trade openness (OPEN) all have positive and significant coefficients for the whole, AE and DE samples. The impact of HC (and thus education) appears to be the same for $\mathrm{AE}$ and DE. OPEN and SAV tend to enhance growth much more (about twice) in AE than in DE. RER appreciations, per se, are expansionary as suggested by the positive rer $_{\text {it }}$ coefficients. However, consistent with the compe- titiveness channel, this impact decreases with higher trade openness. For $\mathrm{AE}$, the net impact of rer $_{\text {it }}$ becomes almost insignificant (decreases to 0.11 ) when evaluated at the mean trade openness $(=0.37-0.90 * 0.29$, where 0.9 is mean openness, 0.37 and 0.29 are the estimated coefficients of OPEN and OPEN*reer, respectively). Consequently, RER appreciations may be interpreted as contractionary or, at best, insignificant in highly open $A E$. The impact of RER through trade openness channel appears to be much more small in DE. The net impact at the mean trade openness $(0.78)$ is around 0.21 which is, indeed, very close to the rer ${ }_{\text {it }}$ coefficient (0.23) in eq. 4.3 of Table 4. This lends a support to the contractionary RER depreciation hypothesis for DE.

Table 3: Unit Root Tests

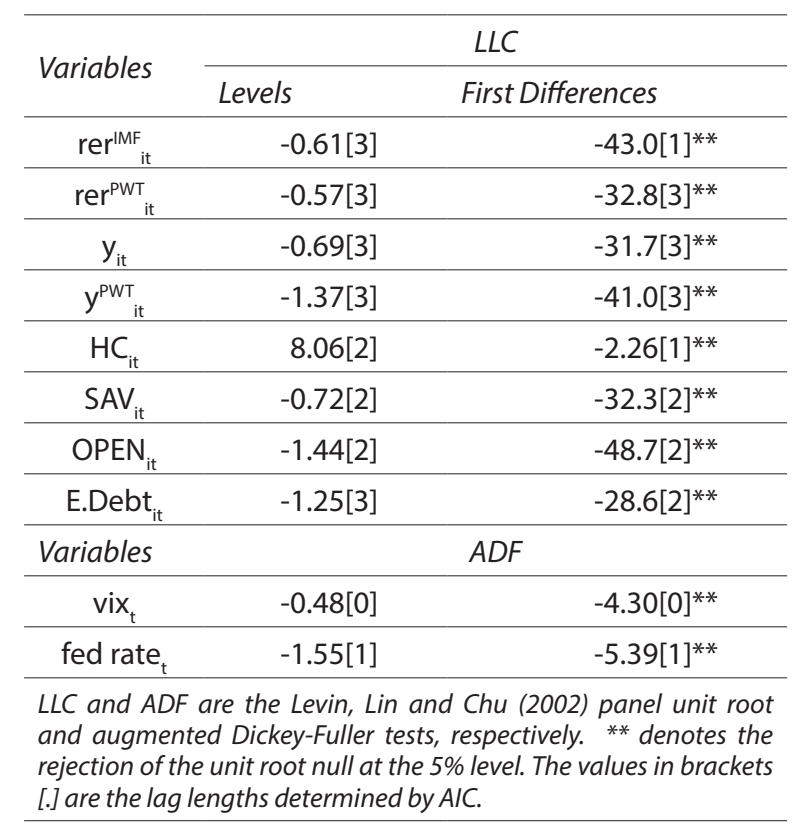

Better global liquidity conditions (a decrease in VIX) and lower FED target rates both have a positive impact on growth in $D E$. The impact of the FED rate for both $A E$ and $D E$ is consistent with a view that "there is a powerful transmission channel of US monetary policy across borders via credit flows, leverage of banks, risk premia and the term spread" (Miranda-Agrippino and Rey, 2015). The results by Kose, Otrok and Prasad (2012) and Erdem and Özmen (2015) suggest that global financial conditions including VIX shocks are amongst the main determinants of business cycles in DE. The significant and negative vix ${ }_{t}$ coefficient is consistent with these studies. Contrasting to the DE evidence, a decrease in the global risk appetite (an increase in VIX) enhances growth in AE. An increase in VIX leads to a risk-aversion 
shock and consequently generates flight-to-quality due to preference to safer assets. The resulting capital flights from $D E$ to $A E$ (or sudden stops of capital inflows to DE) often leads to severe output contractions (or financial crises) in DE. The return to safety appears to enhance growth in $A E$, through potentially mainly capital-flow reversals and the resulting domestic credit expansion.

As already discussed, the presence of high external debt and LD are the main mechanisms of the contractionary devaluation postulation of the BS literature. The direct measures of LD are, unfortunately, available only for a very limited number of DE. Alternatively, we follow Bebczuk, Galindo and Panizza (2006) and define external dollarization as External Debt/GDP (E.Debt) ${ }^{14}$. Such a definition is consistent also with the pioneering contribution by Diaz-Alejandro (1965). World Bank's Global Development Finance data base does not report external debt data for AE. Therefore, equations (4.4) and (4.6) of Table 4 are estimated by using only the DE data.
Higher external debt in DE leads to higher risk premiums, lower credit ratings and thus higher spreads and borrowing costs. The presence of original sin and the consequent BS mismatch potentially alleviate this negative impact. Furthermore, higher external net liabilities and debt increase the risk of financial crises (Bordo, Meisner and Stuckler 2010; Catão and Milesi-Ferretti 2014). Dell'Erba, Hausmann and Panizza (2013) finds that there is a significantly positive correlation between FX debt levels and sovereign spreads (and thus borrowing costs) in DE. Consequently, growth in DE may be expected to decline with higher external debt. The negative and significant E.Debt coefficient estimate in Eq. (4.4) strongly supports this postulation. RER appreciations, on the other hand, have a positive impact on growth as they lead to a decline both external debt and debt service in terms of domestic real income. This is indeed the main channel of the expansionary RER appreciations of the BS literature.

Table 4: RER and Growth: FM-OLS Results

\begin{tabular}{|c|c|c|c|c|c|c|}
\hline $\begin{array}{l}\text { Country } \\
\text { Grouping }\end{array}$ & All & $A E$ & $D E$ & $D E$ & $A E$ & $D E$ \\
\hline Equation & (4.1) & (4.2) & (4.3) & (4.4) & (4.5) & (4.6) \\
\hline $\begin{array}{c}\text { Dependent } \\
\text { variable }\end{array}$ & \multicolumn{4}{|c|}{$y_{\text {it }}$} & \multicolumn{2}{|c|}{$y_{\text {it }}^{P W T}$} \\
\hline reer $_{\text {it }}$ & $0.258^{* *}(0.008)$ & $0.366^{* *}(0.023)$ & $\begin{array}{l}0.227^{* * *} \\
(0.009)\end{array}$ & $0.223^{* *}(0.006)$ & $0.767^{* *}(0.024)$ & $0.304^{* *}(0.011)$ \\
\hline $\mathrm{HC}_{\mathrm{it}}$ & $0.692^{* *}(0.007)$ & $0.665^{* *}(0.016)$ & $\begin{array}{l}0.728^{* *} \\
(0.009)\end{array}$ & $0.733^{* *}(0.005)$ & $1.129 * *(0.016)$ & $0.895^{* *}(0.013)$ \\
\hline $\mathrm{SAV}_{\text {it }}$ & $0.527^{* *}(0.019)$ & $0.991^{* *}(0.041)$ & $\begin{array}{l}0.419^{* *} \\
(0.022)\end{array}$ & $0.516^{* *}(0.013)$ & $1.336 * *(0.036)$ & $0.831^{* *}(0.023)$ \\
\hline OPEN $_{\text {it }}$ & $\begin{array}{l}0.540^{* *} \\
(0.055)\end{array}$ & $1.510^{* *}(0.122)$ & $\begin{array}{l}0.248^{* *} \\
(0.065)\end{array}$ & $\begin{array}{l}0.435^{* *} \\
(0.040)\end{array}$ & $\begin{array}{l}3.011^{* *} \\
(0.153)\end{array}$ & $\begin{array}{l}0.645^{* *} \\
(0.054)\end{array}$ \\
\hline OPEN $_{i t}^{*}$ reer $_{i t}$ & $\begin{array}{l}-0.082^{* * *} \\
(0.012)\end{array}$ & $\begin{array}{l}-0.286^{* *} \\
(0.028)\end{array}$ & $\begin{array}{l}-0.024^{*} \\
(0.013)\end{array}$ & $\begin{array}{l}-0.077^{* *} \\
(0.009)\end{array}$ & $\begin{array}{l}-0.607^{* *} \\
(0.034)\end{array}$ & $\begin{array}{l}-0.122^{* * *} \\
(0.012)\end{array}$ \\
\hline $\operatorname{vix}_{t}$ & $\begin{array}{l}-0.008^{* *} \\
(0.002)\end{array}$ & $0.025^{* *}(0.004)$ & $\begin{array}{l}-0.025^{* *} \\
(0.003)\end{array}$ & $\begin{array}{l}-0.026^{* *} \\
(0.002)\end{array}$ & $0.034^{* *}(0.004)$ & $\begin{array}{l}-0.047^{* * *} \\
(0.004)\end{array}$ \\
\hline fed rate ${ }_{t}$ & $\begin{array}{l}-1.018^{* *} \\
(0.044)\end{array}$ & $\begin{array}{l}-0.915^{* *} \\
(0.070)\end{array}$ & $\begin{array}{l}-1.067^{* *} \\
(0.057)\end{array}$ & $\begin{array}{l}-1.165^{* *} \\
(0.034)\end{array}$ & $\begin{array}{l}-1.149^{* *} \\
(0.036)\end{array}$ & $\begin{array}{l}-1.770^{* *} \\
(0.067)\end{array}$ \\
\hline E.Debt $_{\text {it }}$ & & & & $\begin{array}{l}-0.114^{* *} \\
(0.034)\end{array}$ & & $\begin{array}{l}-0.856^{* *} \\
(0.074)\end{array}$ \\
\hline E.Debt $_{\text {it }}{ }^{*}$ reer $_{\text {it }}$ & & & & $0.037^{* *}(0.008)$ & & $0.198^{* *}(0.016)$ \\
\hline Diagnostics & $\begin{array}{l}N=84 \\
N T=2099 \\
R^{2}=0.99 \\
L R V=0.002 \\
L L C=-10.5 \\
{[0.00]}\end{array}$ & $\begin{array}{l}N=24 \\
N T=667 \\
R^{2}=0.96 \\
L R V=0.002 \\
L L C)=-6.83 \\
{[0.00]}\end{array}$ & $\begin{array}{l}N=60 \\
N T=1431 \\
R^{2}=0.99 \\
L R V=0.002 \\
L L C=-8.56 \\
{[0.24]}\end{array}$ & $\begin{array}{l}N=50 \\
N T=1211 \\
R^{2}=0.98 \\
L R V=0.001 \\
L L C=-8.08 \\
{[0.00]}\end{array}$ & $\begin{array}{l}N=24 \\
N T=667 \\
R^{2}=0.93 \\
L R V=0.002 \\
L L C=-7.32 \\
{[0.00]}\end{array}$ & $\begin{array}{l}N=50 \\
N T=1217 \\
R^{2}=0.97 \\
L R V=0.003 \\
L L C=-7.44 \\
{[0.00]}\end{array}$ \\
\hline
\end{tabular}

Notes: LRV is the long-run variance. Standard errors are given in parentheses. ${ }^{*}$ denotes the significance at the $5 \%$ level. N and NT represents the effective numbers of countries and observations for the sample, respectively. LLC shows the Levin, Li and Chu (2002) panel unit root test statistic for the equation residuals. The optimum lag lengths for the tests are chosen by the AIC. The values in brackets [.] are the p-values for the no cointegration null hypothesis. 
For a robustness check, we consider also $\mathrm{y}^{\mathrm{PWT}}=$ $\ln \left(R^{\prime}\right.$ DP $\left.^{\mathrm{PWT}}\right), \mathrm{RGDP}^{\mathrm{PWT}}$ = per capita real GDP at purchasing power parities ${ }^{15}$ (Feenstra, Inklaar and Timmer 2015). Equations (4.5) and (4.6) in Table 4 reports the results. For the $A E$ sample, we obtain essentially the same results (Eq. 4.5), albeit the coefficient estimates are substantially higher (in absolute values) especially for reer ${ }_{i t^{\prime}} \mathrm{HC}_{\mathrm{it}} \mathrm{OPEN}_{\mathrm{it}}$ and OPEN ${ }^{*}$ reer ${ }_{\mathrm{it}}$. The reer ${ }_{\mathrm{it}}$ cooefficient is still positive (0.79) but, again, tends to vanish when considered along with the competitiveness impact $(-0.61)$. For the DE sample, on the other hand, the earlier findings for $y_{\text {it }}$ remains almost unchanged for $y_{\text {it }}{ }^{\text {PWT }}$.

\section{Concluding Remarks and Policy Implications}

RER depreciations increase the value of FX debt and debt service in terms of domestic currency and deteriorate financial positions of the debtor sectors of an economy. Consequently, RER depreciations may be contractionary for DE with higher FX debt as argued by Diaz-Alejandro (1965) much earlier. We find that balance sheet effects, captured by the interaction between RER and $F X$ debt have a significant and negative impact on output in DE. This result provides a strong support for the Diaz-Alejandro (1965) proposition and some related studies including Ahmed, Kamin and Huntley (2002), Galindo, Panizza and Schiantarelli (2003), Cespedes, Chang and Velasco (2003), Céspedes (2005), Bebczuk, Galindo and Panizza (2006) and Frankel $(2005,2011)$. Our data, on the other hand, support that RER depreciations are expansionary (or at least not contractionary) for $\mathrm{AE}$.

Another important finding of our paper is that, the studies interpreting "undervaluation" variable coefficient as a support for expansionary depreciations postulation may be misleading and thus should be interpreted with an extreme caution. This is because, these coefficients may, indeed, be representing error/ equilibrium correction mechanism to deviations from cointegration between RER and per capita real income.

Higher trade openness decreases the contractionary impact of RER depreciations in both AE and $D E$. This international competitiveness affect is much higher in $\mathrm{AE}$ than $\mathrm{DE}$. Consequently, the net impact of RER appreciations becomes contractionary or, at best, insignificant in highly open AE.

We also find that external variables representing global financial (VIX) and monetary (FED funds target rate) conditions are strongly significant in explaining growth in DE along with the conventional domestic variables including trade openness, human capital, domestic savings. An increase in the FED rate leads to an output decline in both $\mathrm{AE}$ and $\mathrm{DE}$. Contrasting to the $D E$ evidence, a decrease in the global risk appetite (an increase in $\mathrm{VIX}$ ) enhances growth in $\mathrm{AE}$. This is consistent with the sudden stops or capital-flow reversals from $D E$ to $A E$ due to the flight-to quality mechanism during turbulent times. The impact of $\mathrm{HC}$ (and thus education) appears to be the same for $A E$ and $D E$. Trade openness and domestic savings tend to enhance growth much more (about twice) in AE than in DE.

The main tenet of the "mercantilist view" is exportled growth through systematic RER depreciation. According to Ahmed, Kamin and Huntley (2002), on the other hand, RER elasticity of exports has substantially declined during the recent decades due to higher degree of globalization of production and trade. In this process, which is called global value chains (Johnson, 2014) or global supply chains (Baldwin and Lopez-Gonzalez, 2015), production of final product is sliced up into different stages and tasks are distributed among different countries. As countries has become more dependent on imports for production and exports, complementarity of exports and imports has increased (Johnson 2014; Baldwin and Lopez-Gonzalez 2015). A RER depreciation, improves the competitiveness of domestic value added in exports and increases the cost of imported inputs leading to a decrease in the RER elasticity of trade. Together with the BS effect of RER depreciation in countries with higher FX debt, the decline in the RER elasticity of exports with higher integration to global value/supply chains, provides another plausible explanation and a promising research agenda for the expansionary RER appreciation postulation.

According to Guzman, Ocampo and Stiglitz (2018) a competitive RER is crucial for the generation of backward and forward linkages of existing economic activities and should be complemented with industrial policies. In the international trade context, an industrial policy aiming to increase forward participation (the use of domestic intermediates in third country exports) and decrease backward participation (the use of foreign inputs in exports) appears to be strategically important for a higher sustainable growth in DE.

Better education (higher human capital), higher savings and trade openness are amongst the complementary tools of higher sustainable growth. Lower levels of LD and FX debt are necessary for a successful 
export-led growth strategy. However, all these require macroeconomic stability. The literature, unfortunately, is yet to provide a convincing answer how a systematic undervalued currency can be achieved under a flexible exchange rate regime and inflation targeting (Woodford, 2008).

The importance of exogenous global factors for growth of DE does not necessarily relegate the importance of domestic fundamentals and macroprudential regulations. The domestic fundamentals, including FX debt and LD, are indeed, amongst the main mechanisms through which the impacts of exogenous shocks are transmitted. Given the results that global financial and monetary conditions are crucially important for DE growth, the success of a sustained undervalued RER may become more ambiguous. The recent studies on the "impossible trinity", including Rey $(2015,2016)$, Aizenman, Chinn and Ito (2015) and Obstfeld (2015), indeed, provide important insights and a promising research agenda also for investigating RER and growth relationships. 


\section{References}

Ahmed, S., Gust, C., Kamin, S. \& Huntley, J. (2002). Are depreciations as contractionary as devaluations? A comparison of selected emerging and industrial economies. FRB International Finance Discussion Paper No. 737.

Ahmed, S., Appendino, M. \& Ruta, M. (2015). Depreciations without exports? Global value chains and the exchange rate elasticity of exports. World Bank Policy Research Working Paper No. 7390.

Aizenman, J., Chinn, M. \& Ito, H. (2015). Monetary policy spillovers and the trilemma in the new normal: periphery country sensitivity to core country conditions. NBER Working Paper 21128.

Almansour, A., Aslam, A., Bluedorn, J. \& Duttagupta, R. (2015). How vulnerable are emerging markets to external shocks? Journal of Policy Modeling, 37(3), 460-483.

Alper, A. M. \& Civcir, I. (2012). Can overvaluation prelude to crisis and harm growth in Turkey? Journal of Policy Modeling, 34(1), 112-131.

Bahadir, B. \& Lastrapes, W. D. (2015). Emerging market economies and the world interest rate. Journal of International Money and Finance, 58, 1-28.

Baldwin, R. \& Lopez-Gonzalez, J. (2015). Supply-chain trade: a portrait of global patterns and several testable hypotheses. The World Economy, 38(11),1682-1721.

Barro, R. J. (2015). Convergence and modernisation. The Economic Journal, 125, 911-942.

Bebczuk, R., Galindo, A. \& Panizza, U. (2006). An evaluation of the contractionary devaluation hypothesis. Inter-American Development Bank Working Paper No. 582.

Bordo, M. D., Meissner, C. M. \& Stuckler, D. (2010). Foreign currency debt, financial crises and economic growth: A long-run view. Journal of International Money and Finance, 29(4), 642-665.

Bussiere, M., Lopez, C. \& Tille, C. (2015). Do real exchange rate appreciations matter for growth? Economic Policy, January, $1-41$.

Calderón, C. \& Fuentes, J. R. (2012). Removing the constraints for growth: Some guidelines. Journal of Policy Modeling, 34(6), 948-970.

Calvo, G. A., Leiderman L. \& Reinhart, C.M. (1993). Capital inflows and real exchange rate appreciation in Latin America -The role of external factors. IMF Staff Papers, 40(1), 108-51.

Calvo, G.A. \& Reinhart, C. (2002). Fear of floating. The Quarterly Journal of Economics, 117(2), 379-408.

Calvo, G.A., Izquierdo A. \& Mejía, L.F. (2004). On the empirics of sudden stops: the relevance of balance sheet effects. NBER Working Paper No. 11492.

Catão, L.A.V.\& Milesi-Ferretti, G.M. (2014). External liabilities and crises. Journal of International Economics, 94(1), 18-32.
Céspedes, L.F. (2005). Financial frictions and real devaluations. Central Bank of Chile Working Papers No. 318.

Cespedes, L.F., Chang, R. \& Velasco, A. (2003). IS-LM-BP in the pampas. IMF Staff Papers, 50(1), 143-156.

Chudik, A. \& Pesaran, M. H. (2015). Large panel data models with cross-sectional dependence: a survey. In The Oxford Handbook of Panel Data (B. H. Baltagi, Ed.). 3-45. Oxford University Press, New York.

Cline, W.R. (2015). Further statistical debate on "too much finance". Peterson Institute for International Economics WP $15-16$

Dell'Erba, S., Hausmann, R. \& Panizza, U. (2013). Debt levels, debt composition, and sovereign spreads in emerging and advanced economies. Oxford Review of Economic Policy, 29(3), 518-547.

Diaz Alejandro, C. (1965). Exchange rate devaluation in a semi-industrialized country. MIT Press, Cambridge, United States.

Di Nino, V., Eichengreen, B. \& Sbracia, M. (2011). Real exchange rates, trade, and growth: Italy 1861-201. Bank of Italy Working Paper No: 10.

Eberhardt, M. \& Teal, F. (2011). Econometrics for grumblers: a new look at the literature on cross-country growth empirics. Journal of Economic Surveys, 25(1), 109-155

Eichengreen B. (2008). The real exchange rate and economic growth. World Bank Growth Commission Working Paper No. 4.

Eichengreen, B., Hausmann, R., \& Panizza, U. (2003). Currency mismatches, debt intolerance and original sin: why they are not the same, why it matters. NBER Working Paper No. 10036.

Erdem, F. P. \& Özmen, E. (2015). Exchange rate regimes and business cycles: an empirical investigation. Open Economies Review, 26(5), 1041-1058.

Feenstra, R. C., Inklaar, R. \& Timmer, M. P. (2015). The next generation of the Penn World Table. American Economic Review, 105(10), 3150-3182.

Frankel, J.A. (2005). Mundell-Fleming lecture: contractionary currency crashes in developing countries. IMF Staff Papers, 55(2), 149-192.

Frankel, J.A. (2011). Monetary policy in emerging markets, in Handbook of Monetary Economics, (B. Friedman and M. Woodford, Eds.) Vol. 3B: 1439-1520 (North Holland: The Netherlands).

Galindo, A., Panizza, U. \& Schiantarelli, F. (2003). Debt composition and balance sheet effects of currency depreciation: a summary of the micro evidence. Emerging Markets Review, 4, 330-339. 
Gluzmann, P., Levy-Yeyati E. \& Sturzenegger, F. (2012). Exchange rate undervaluation and economic growth: Díaz Alejandro (1965) revisited. Economic Letters, 117, 666-672.

Gonzalez-Rozada, M. \& Levy-Yeyati, E. (2008). Global factors and emerging market spreads. The Economic Journal, 118 (533), 1917-1936.

Guzman, M., Ocampo J. A. \& Stiglitz J. E. (2018). Real exchange rate policies for economic development. World Development, 110, 51-62.

Habib, M. M., Mileva, E. \& Stracca, L. (2017). The real exchange rate and economic growth: Revisiting the case using external instruments. Journal of International Money and Finance, 73, 386-398.

IMF (2004). Global financial market developments. Global Financial Stability Report (April, Ch. 2. IMF).

Johnson, R.C. (2014). Five facts about value-added exports and implications for macroeconomics and trade research. Journal of Economic Perspectives, 28(2), 119-142.

Kesriyeli, M., Özmen, E. \& Yiğit, S. (2011). Corporate sector liability dollarization and exchange rate balance sheet effect in Turkey. Applied Economics, 43(30), 4741-4747.

Kose, A., Otrok, C. \& Prasad, E.S. (2012). Global business cycles: Convergence or decoupling? International Economic Review, 87, 178-90.

Krugman, P. (1999). Balance sheets, the transfer problem and financial crises. International Tax and Public Finance, 6, 459472.

Lane, P. R. \& Stracca, L. (2018). Expansionary Appreciation. Economic Policy, April, 225-264.

Levin, A., Lin, C. F. and Chu, C. S. J. (2002). Unit root tests in panel data: asymptotic and finite-sample properties. Journal of econometrics, 108(1), 1-24.

Levy-Yeyati, E., Sturzenegger, F. \& Gluzmann, P.A. (2013). Fear of appreciation. Journal of Development Economics, 101, 233-247.

Miranda-Agrippino, S. \& Rey, H. (2015). World asset markets and the global financial cycle. NBER Working Paper No. 21722.

Montiel, P. J. \& Serven, L. (2008). Real exchange rates, saving and growth: is there a link?, World Bank Policy Research Working Paper No. 4636.
Nouira, R. \& Sekkat, K. (2012). Desperately seeking the positive impact of undervaluation on growth. Journal of Macroeconomics, 34(2), 537-552.

Obstfeld, M. (2004). Globalization, macroeconomic performance, and the exchange rates of emerging economies. Monetary and Economic Studies, 22(1), 29-55.

Obstfeld, M. (2015). Trilemmas and trade-offs: living with financial globalisation. BIS Working Papers No 480.

Özatay, F., Özmen, E. \& Sahinbeyoglu, G. (2009). Emerging market sovereign spreads, global financial conditions and U.S. macroeconomic news. Economic Modelling, 26(2), 526-531.

Özmen, E. \& Yaşar, Ö. D. (2016). Emerging market sovereign bond spreads, credit ratings and global financial crisis. Economic Modelling, 59: 93-101.

Pedroni, P. (2000). Fully-modified OLS for heterogeneous cointegrated panels. Advances in Econometrics, 15, 93-130.

Pedroni, P. (2004). Panel cointegration; asymptotic and finite sample properties of pooled time series tests with an application to the PPP Hypothesis. Econometric Theory, 20(3), 597-625.

Pedroni, P. (2007). Social capital, barriers to production and capital shares; implications for the importance of parameter heterogeneity from a nonstationary panel approach. Journal of Applied Econometrics, 22, 429-51.

Pesaran, M.H., Shin, Y. \& Smith, R.P. (1999). Pooled mean group estimation of dynamic heterogeneous panels. Journal of the American Statistical Association, 94, 621-634

Rey, H. (2015). Dilemma not trilemma: The global financial cycle and monetary policy independence. NBER Working Paper No. 21162.

Rey, H. (2016). International channels of transmission of monetary policy and the Mundellian trilemma. NBER Working Paper No. 21852.

Rockey, J \& Temple, J. (2016). Growth econometrics for agnostics and true believers. European Economic Review, 8, 86-102

Rodrik, D. (2008). The real exchange rate and economic growth. Brookings Papers on Economic Activity, Fall, 365-412.

Woodford, D. (2008). The real exchange rate and economic growth: comment. Brookings Papers on Economic Activity, Fall, 420-437. 


\section{Appendix}

Table A1. Data Sources

\begin{tabular}{|c|c|}
\hline GDP, per capita real GDP at constant 2010 USD. & World Bank, World Development Indicators (WDI) \\
\hline GDP, per capita real GDP at chained PPPs. & PENN World Table, Version 9.0, Feenstra, et. al., (2015) \\
\hline$R E R^{I M F}$, real effective exchange rates & $\begin{array}{l}\text { IMF-IFS, Bank for International Settlements }{ }^{a} \text { and Inter- } \\
\text { American Development Bank }{ }^{b}\end{array}$ \\
\hline REER ${ }^{P W T}$, real effective exchange rates & $\begin{array}{l}\text { PENN World Table, Version } 9.0 \\
\text { Feenstra, et. al., (2015) }\end{array}$ \\
\hline HC, human capital per worker & $\begin{array}{l}\text { PENN World Table, Version } 9.0 \\
\text { Feenstra, et. al., (2015) }\end{array}$ \\
\hline Population & $\begin{array}{l}\text { PENN World Table, Version } 9.0 \\
\text { Feenstra, et. al., (2015) }\end{array}$ \\
\hline $\begin{array}{l}\text { OPENNESS, trade openness (expressed as the sum of exports } \\
\text { and imports over GDP) }\end{array}$ & World Bank, WDI \\
\hline SAV, domestic savings (as a share of GDP). & World Bank, WDI \\
\hline E.Debt External Debt/GDP & World Bank, WDI and Global Development Finance database. \\
\hline VIX, Volatility implicit in U.S. stock options & Bloomberg \\
\hline$R^{F E D}$, Effective FED Funds target rate & Federal Reserve Board \\
\hline
\end{tabular}

Notes: a. RER ${ }^{\text {IMF }}$ data for Iceland, India, Indonesia, Korea R., Lithuania, Slovenia, Thailand, Turkey and Estonia are from Bank for International Settlements (BIS) database.

b. $R E R^{\text {IMF }}$ data for Argentina, Guatemala, Haiti, Honduras, Jamaica and Peru are from Inter-American Development Bank (IADB).

c. External Debt/GDP data for Argentina, Bahamas, Chile and Uruguay are from IADB.

Table A2. Country List

\begin{tabular}{|c|c|c|c|c|}
\hline \multicolumn{2}{|l|}{ Advanced (AE) } & \multicolumn{3}{|c|}{ Developing or Emerging (DE) } \\
\hline Australia Austria & Spain Sweden & Algeria & Estonia & Nigeria \\
\hline Belgium & Switzerland & Argentina & Fiji & Pakistan \\
\hline Canada & U. Kingdom U. States & Armenia & Gabon & Paraguay \\
\hline Denmark Finland & & Bahamas & Gambia & Peru \\
\hline France Germany & & Belize & Ghana & Philippines Poland \\
\hline Greece & & Bolivia & Guatemala & Romania \\
\hline Iceland & & Brazil & Guyana & Russian F. \\
\hline Israel & & Bulgaria & Haiti & Sierra Leone \\
\hline Italy, & & Burundi & Honduras & Slovakia \\
\hline Japan, Luxembourg & & Cameroon & Hungary & Slovenia \\
\hline Malta & & C.African R. & India & S. Africa \\
\hline Netherlands N. & & Chile & Indonesia & Thailand \\
\hline Zealand Norway & & China & Iran & Togo \\
\hline Portugal & & Colombia & Jamaica & Tunisia \\
\hline \multirow[t]{8}{*}{ Singapore } & & Costa Rica & Korea R. & Turkey \\
\hline & & Cote D'Ivore & Latvia & Uganda \\
\hline & & Croatia & Lesotho & Ukraine \\
\hline & & Cyprus & Lithuania & Uruguay \\
\hline & & Czech R. & Malawi & Venezuela \\
\hline & & Dominica & Malaysia & Zambia \\
\hline & & Dominican R. & Mexico & \\
\hline & & Ecuador & Morocco & \\
\hline
\end{tabular}




\section{Endnotes}

1 Obstfeld (2004, p. 42) cites Diaz-Alejandro (1965, p. 31) “Devaluation may produce another type of wealth effect when some groups of the country have debts to foreigners expressed in terms of foreign currencies. A devaluation will then increase the value of the debt expressed in domestic currencies and will exert a depressing influence on the expenditures of these groups, especially when the domestic prices they receive for the sale of their products or services do not increase proportionally with the devaluation. When a country has a net foreign debt, this effect will make more likely an improvement in the trade balance and a drop in output following devaluation, especially when the debt is held by the private sector and is concentrated in short-term maturities".

2 Rodrik (2008) uses 5-year averages and includes also an initial income variable. Following Pedroni (2007), we do not include an initial income variable in cointegrating equations. However, our results from these equations are consistent with the findings of Rodrik (2008).

3 This procedure, however, may be subject to serious empirical modelling issues as convincingly argued by Woodford (2008).

4 The Pedroni (2004) residual-based panel cointegration test (panel Phillips-Perron statistics estimated with lag length 3) yielded -18.0 for $\mathrm{y}_{\mathrm{it}}$ and rer ${ }_{\mathrm{it}}{ }^{\mathrm{PWT}},-29.2$ for $\mathrm{y}_{\mathrm{it}}$ and rer ${ }_{\mathrm{it}}{ }^{\mathrm{MMF}}$. This provides a further support for the presence of cointegration between the variables.

5 Gluzmann, Levy-Yeyati and Sturzenegger (2012) also uses the lagged values of the UNDERVAL variable to estimate (2).

6 We started with a maximum lag of PARDL-MG $(4,4)$ and the optimum lag lengths of the equations are chosen by the likelihood ratio tests of sequential lag length reduction.

7 As noted by Pedroni (2007), the use of panel cointegration techniques allows to relax to continuous steady-state position of the conventional growth literature. The stationarity of residuals of the real income equation (thus the presence of a cointegration) is a necessary condition for income convergence. Consequently, Pedroni (2007) argues that there is no need to specify a lagged dependent variable (initial income) term as in the conventional convergence equations. Furthermore, the estimation of a cointegrating equation with an initial income variable is often not feasible. Therefore, we do not include this variable. Also note that, in the presence of an initial income variable which is often constant for individual countries, the estimation of the conventional models with an intercept term by employing a cross-section fixed effects procedure is not feasible due to perfect multicollinearity. Because of this, the empirical models containing a constant initial income variable do not include an intercept term. However, this may result in an identification problem as the initial income coefficient may indeed be representing the intercept term rather than convergence.

8 We considered also rer $^{\mathrm{PWT}}$ it and obtained essentially similar results with rer $^{\mathrm{IMF}}{ }_{\text {it }}$.

9 See, Eberhardt and Teal (2011), Calderon and Fuentes (2012), Barro (2015) and Rockey and Temple (2016) for the recent surveys.

$10 \operatorname{IMF}(2004$, p.68) notes that, "measures of short-term rates, such as the Fed Funds target rate or three-month treasury bill rates, are very closely correlated with the three-month LIBOR rate".

11 Econometric theory is yet to provide a support to the use of PARDL-MG procedure in the presence of large number of regressors relative to the time span of the panel along with the inclusion of interaction variables. Therefore, Eq, 6 is not estimated by PARDLMG.

12 The results are found to be robust to different country groupings and to the use of other commonly used unit root tests. These results are not reported to save the space but available on request.

13 Note that, these residuals based cointegration tests maintains that there can be only one within group cointegration in the panel.

14 Bebczuk, Galindo and Panizza (2006) multiplies E.Debt with the original sin (OSIN) measure built by Eichengreen et al. (2003). As the OSIN has very limited time variability, we maintain that it is unity for DE.

15 According to Cline $(2015$, p.5) "testing cross-country growth patterns without permitting a comparable cross-country level of real per capita income is a classic instance of staging Hamlet without the Prince of Denmark. 